\title{
GAÁL GYULA
}

\section{Az embercsempészés büntetőjogi aspektusból}

Az embercsempészés egyidős az államhatárokkal. A migráció nem kívánt velejárója, amely újból és újból kinő, mint a hidra levágott feje. Kereslet van iránta, az elvándorlók, menekülők megfizetik. ${ }^{1}$

\section{Az embercsempészés hazai büntetőjogi szabályozásának története}

A jogalkotás folyamatában az embercsempészést mint sui generis bủncselekményt viszonylag későn szabályozták a magyar büntető törvénykönyvben (Btk.). A jogalkotó a tiltott határátlépés bünsegélyi alakzatát minősítette önálló büncselekménynek, és súlyosabban szankcionálta, mint azt a tényállást, amelyből eredt. Az embercsempészés késői kodifikálása ellenére távoli előzményeit már a századforduló környékén megtaláljuk, bár még nem a tiltott határátlépés bünsegélyi alakzatához kapcsolódóan. ${ }^{2}$

A kivándorlási ügynökségekröl szóló 1881 . évi XXXVIII. törvényczikk kihágássá minősítette a kivándorlás tiltott közvetítését. ${ }^{3}$ E cselekmény jogi szabályozásának oka arra vezethető vissza, hogy a korabeli Magyarország némely vidékéről jelentősen megnőtt, különösen a munkásosztály tagjainak elsősorban Amerikába történő - tömeges kivándorlása, amely legtöbb esetben egyes ügynökök, üzérkedők rábeszélésének, csábításának a következménye volt, akik így szerezték meg a kivándorlók csekély vagyonát, vagy kül-

\footnotetext{
1 Fórizs Sándor: Előszó. In: Gaál Gyula: Az embercsempész tevékenység megjelenési formáinak és módszereinek változásai a Magyar Köztársaság államhatárán 1991-2003 között. Doktori (PhD) értekezés. Zrínyi Miklós Nemzetvédelmi Egyetem, Budapest, 2005, 4. o.

2 Verhóczki János: Az embercsempészés a mai magyar büntetőjogban. Magyar Rendészet, 2000/5-6., 28. o.

3 1881. évi XXXVIII. tc. „2. § Aki ily engedély nélkül a kivándorlást közvetiti, mennyiben ezen tette közbena büntetötörvények súlya alá eső cselekményt nem követett el, kihágást követ el, s annyiszor, amennyiszer, háromszáz forintig terjedhető pénzbüntetéssel és két hónapig tartható elzárással büntethetö, azon hatóságok által és azon eljárás szerint, melyeket az 1880. évi XXXVII. törvényczikk alapján kiadott belügyminiszteri rendelet megállapit." Corpus Juris Hungarici CD, Budapest, 1996
} 
földi ügynökségektől magasabb fizetést kaptak a minél több kivándorlás közvetítéséért. ${ }^{4}$

A jogtörténeti visszatekintésben az 1903. évi VIII. törvényczikk a határrendőrség feladatává tette a nőcsempészet megakadályozását: „,2. $\S$ j) nöcsempészet megakadályozása". Az állam biztonságát közvetlenül érintő érdekeken, így az ország határszakaszainak állandó felügyelet alatt tartásán, az azokon átirányuló forgalom folytonos ellenörzésén és a határ közelében felvetődő jelentékenyebb események figyelemmel kísérésén túl, az újonnan létrehozott szervezet, a határrendőrség további fontos feladata lett a déli határszakaszon nagyban üzött nőcsempészet megakadályozása. „,Szomorú tény, hogy a szerbiai, romániai, de az egész Balkán félszigeten lévö bordélyházak nagyrészt magyarországi származású leányokkal vannak benépesitve. E fiatal leányok többnyire szolgálat vagy egyéb foglalkozás ürügye alatt lelketlen ügynökök által csábittatnak ki és ezután az erkölcstelenség fertöjébe taszittatnak. Ez az aljas lélekkufárság, daczára az ismételve tett intézkedéseknek, eddig nagyrészt a határszéli rendöri szolgálat elégtelensége miatt nem volt meggátolható, miért is e rendöri szolgálat szervezése folytán ezen a téren is lényeges javulás várható."

Az 1908. évi XXXVI. törvényczikk 45. § (3) bekezdése a kerítés minősített eseteként határozta meg, ha az elkövetö külföldre szállította a nőt. ${ }^{6}$

A jelenlegi fogalmaink szerinti embercsempészés a büntetőtörvényeink között először a tiltott határátlépés tényállásán keresztül jelent meg a büntetőtörvények egyes fogyatékosságainak megszüntetéséről és pótlásáról szóló 1948. évi XLVIII. törvényczikk 48. § (3) bekezdésében. A bekezdés a tiltott útlevélhasználathoz és a tiltott határátlépéshez nyújtott segítséget büntette öt évig terjedő börtönbüntetéssel, hivatalvesztéssel és a politikai jogok gyakorlásának felfüggesztésével. ${ }^{7}$ A szabályozásnak az volt a jelentősége, hogy a

\footnotetext{
4 Az 1881. évi XXXVIII. tc. indokolása. Corpus Juris Hungarici CD, Budapest, 1996

5 Az 1903. évi VIII. tc. indokolása. Corpus Juris Hungarici CD, Budapest, 1996

6 1908. évi XXXVI. tc. „,45. § Tekintet nélkül a sértett nö korára és erkölcsiségére, a kerités büntett, ha a tettes: 1) csalárdsággal, eröszakkal vagy fenyegetéssel követi el; 2) a cselekményt hozzátartozója (Btk. 78. §), nevelés, tanitás vagy felügyelet végett rábízott, vagy neki alárendelt nö ellen követi el; 3) a nöt külföldre szállítja vagy szállittatja; 4) a kerítéssel üzletszerüleg foglalkozik, vagy kerítés miatt már egyszer büntetve volt, büntetésének kiállitása óta tíz év még el nem telt." Corpus Juris Hungarici CD, Budapest, 1996

7 1948. évi XLVIII. tc. „, 48. § (3) Büntett miatt öt évig terjedhetö börtönnel, hivatalvesztéssel és politikai jogai gyakorlásának felfüggesztésével büntetendö, aki másnak az (1) bekezdésben meghatározott valamely cselekmény elkövetésére segitséget nyújt. (4) A (3) bekezdés alá tartozó büntett föbüntetése öt évig terjedhetö fegyház, ha az csoportos határátlépés elömozdítására irányult." Corpus Juris Hungarici CD, Budapest, 1996
} 
jogalkotó ezzel az aktussal a fogalmilag bünsegédi magatartást önálló tettesi cselekménnyé nyilvánította.

Az ország területének elhagyására vonatkozó büntetőrendelkezések kiegészítéséről szóló 1957. évi 12. számú törvényerejü rendelet az 1948. évi XLVIII. törvényczikk 48. § (3) bekezdését kiegészítette egy minősített esettel. Egytől tíz évig terjedő börtönbüntetéssel és vagyonelkobzással sújtotta a rendszeres vagy üzletszerü segítségnyújtást. A hozzátartozókon kívül bevezette a feljelentés elmulasztása miatti felelősségre vonást is, egyelőre csak ebben az egy minősített esetben. ${ }^{8}$

Az embercsempészés az 1961. évi V. törvény 204. §-ában jelent meg elöször önállóan a közbiztonság elleni büntettek között, amely csak az üzletszerủ segítségnyújtást büntette. Szankcionálta viszont az elökészület egyes fordulatait, a segítségnyújtásra való ajánlkozást, illetve az összebeszélést. Mellékbüntetésként megjelent a vagyonelkobzás és a kitiltás is. ${ }^{9}$

Az önálló büncselekménnyé nyilvánítás azzal magyarázható, hogy a tiltott határátlépés elősegítése a társadalomra veszélyesebb, mint maga a tiltott határátlépés, mivel egyfelől a bünsegéd részéről a további bünelkövetés veszélye is fennáll, másfelől az ilyen magatartást tanúsító személy rendszerint jelentékeny jogtalan haszonhoz is jut társadalmilag hasznos munka végzése nélkül. ${ }^{10}$

Az 1978. évi IV. törvény a rendészeti büncselekmények közé sorolta az embercsempészést. Az követte el a büncselekményt, aki tiltott határátlépéshez vagyoni haszonszerzés végett vagy az ilyen cselekményeket elösegíto szervezet tagjaként vagy megbízásából segítséget nyújtott, erre ajánlkozott vagy vállalkozott. Az üzletszerü elkövetés minősített esetként szerepelt. ${ }^{11}$

\footnotetext{
8 1957. évi 12. számú tvr. „2. § Aki tiltott határátlépés elkövetésére irányuló hírverést fejt ki, vagy másokat e cselekmény elkövetésére felhív, hat hónaptól öt évig terjedhetö börtönnel büntethetö. 3. § (1) Aki tiltott határátlépéshez rendszeresen vagy üzletszerüen segitséget nyújt, egy évtöl tíz évig terjedhető börtönnel és vagyonelkobzással büntetendö. (2) Aki hitelt érdemlö tudomást szerez arról, hogy az (1) bekezdésben meghatározott büntett elkövetése készül vagy ilyen büntettet elkövettek és erröl a hatóságnak, mihelyt teheti, jelentést nem tesz két évig terjedhetö börtönnel büntetendö. Az elkövetö hozzátartozója (1950.évi II. törvény 29. §) a feljelentés elmulasztása miatt nem büntethetö.” Corpus Juris Hungarici CD, Budapest, 1996

9 1961. évi V. tv. „204. § Aki tiltott határátlépéshez üzletszerüen segitséget nyújt, erre ajánlkozik vagy összebeszél, ha súlyosabb büntett nem valósult meg, két évtöl nyolc évig terjedö szabadságvesztéssel büntetendö. Mellékbüntetésként vagyonelkobzásnak és kitiltásnak is helye van." Corpus Juris Hungarici CD, Budapest, 1996

10 Földvári József: Büntetőjog Különös Rész. Janus Pannonius Tudományegyetem Állam- és Jogtudományi Kar-Tankönyvkiadó, Budapest, 1972, 224. o.

11 1978. évi IV. tv. „,218. § (1) Aki tiltott határátlépéshez vagyoni haszonszerzés végett vagy az ilyen cselekményeket elösegitö szervezet tagjaként vagy megbizásából segitséget nyújt, erre ajánlkozik vagy vállalkozik, büntettet követ el, és két évtöl nyolc évig terjedö szabadságvesztéssel büntetendö. (2) A bün-
} 
Az embercsempészés tényállása az elmúlt negyedszázad alatt többször módosult. A külföldre utazásról és az útlevélröl szóló 1989. évi XXVIII. törvény 20. $\S(2)$ bekezdése a tiltott határátlépés dekriminalizációjának megfelelően módosította az embercsempészés tényállását. Az (1) bekezdésben a tiltott határátlépéshez (Btk. 217. §) nyújtott segítséget szankcionálta a jogalkotó, a (2) bekezdésben pedig a tiltott határátlépés szabálysértési alakzata elkövetöjének nyújtott segítséget büntette. ${ }^{12}$ Kikerültek a szabályozásból az előkészületi magatartások, és az eddig minősített esetként megjelenő üzletszerüség is. A 20. § (1) bekezdése törölte az eddig fennálló feljelentési kötelezettséget is. ${ }^{13}$

Az 1993. évi XVII. törvény a mellékbüntetések közül törölte a vagyonelkobzást és csak a kitiltást hagyta meg.

Az 1990-es években az embercsempészés növekedése és szervezetté válása a büntetőjogi szabályozás szigorításával járt. Az 1997. évi LXXIII. törvény a tiltott határátlépés szabálysértéshez nyújtott segítség esetén is bevezette a vagyoni haszonszerzés miatti célzatot, minősített esetként értékelte a bünszervezet tagjaként vagy megbízásából megvalósuló cselekményt, és büntetni rendelte az embercsempészésre irányuló előkészületet. Az 1998. évi LXXXVII. törvény 52. §-a a büntetési tételeket megemelte, így minden elkövetési magatartás büntettnek minősült. ${ }^{14}$

tetés öt évtöl tíz évig terjedö szabadságvesztés ha az embercsempészést üzletszerüen követik el. (3) Az embercsempészés elkövetöjével szemben mellékbüntetésként vagyonelkobzásnak és kitiltásnak is helye van. ” Corpus Juris Hungarici CD, Budapest, 1996

$12 \mathrm{Az}$ 1989. évi XXVIII. törvény módosította a tiltott határátlépés bűntettének tényállását is. Hatályon kívül helyezte az eredeti diszpozíciót, és a korábban minősítő körülményként szerepeltetett fegyveresen történő elkövetést alapeseti tényállási elemként fogalmazta meg. A változás következtében a tiltott határátlépésnek szabálysértési alakzata is lett.

13 1989. évi XXVIII. tv. „218. § (1) Aki tiltott határátlépéshez (217. §) vagyoni haszonszerzés végett vagy ilyen cselekményeket elösegitö szervezet tagjaként vagy megbizásából segitséget nyújt, büntettet követ el, és öt évig terjedö szabadságvesztéssel büntetendö. (2) Aki az (1) bekezdésben meghatározott módon a Magyar Köztársaság államhatárának engedély nélküli vagy meg nem engedett módon történö átlépéséhez segitséget nyújt, vétséget követ el, és két évig terjedö szabadságvesztéssel büntetendö. (3) Az embercsempészés elkövetőjével szemben mellékbüntetésként vagyonelkobzásnak és kitiltásnak is helye van." Corpus Juris Hungarici CD, Budapest, 1996

14 „Btk. 218. § (1) Aki tiltott határátlépéshez (217. §) vagyoni haszonszerzés végett segitséget nyújt, büntettet követ el, és két évtöl nyolc évig terjedő szabadságvesztéssel büntetendö. (2) Aki a Magyar Köztársaság államhatárának engedély nélkül vagy meg nem engedett módon történö átlépéséhez vagyoni haszonszerzés végett segitséget nyújt, büntettet követ el, és három évig terjedö szabadságvesztéssel büntetendö. (3) Aki a cselekményt bünszervezet tagjaként vagy megbizásából követi el, büntett miatt az (1) bekezdés esetén öt évtöl tíz évig, a (2) bekezdés esetén két évtöl nyolc évig terjedö szabadságvesztéssel büntetendö. (4) Aki az (1)-(3) bekezdésben meghatározott embercsempészésre irányuló elökészületet követ el, vétség miatt két évig terjedö szabadságvesztéssel büntetendö. (5) Az embercsempészés elkövetöjével szemben mellékbüntetésként kitiltásnak is helye van." 
A 2002. április 1-jén hatályba lépő 2001. évi CXXI. törvény az embercsempészésnek mind az alapesetét, mind a minősített eseteit módosította. $\mathrm{E}$ törvény hatálybalépéséig az embercsempészés tényállásának valamennyi szabályozását a tiltott határátlépés büncselekményhez való kapcsolódás jellemezte, azonban a jogalkotó a tiltott határátlépés büntettét arra figyelemmel hatályon kívül helyezte, hogy a Magyar Köztársaság államhatárának jogellenesen, fegyveresen történő átlépése adott esetben megvalósítja a visszaélés robbanóanyaggal vagy robbantószerrel (Btk. 263. §), illetve a visszaélés löfegyverrel vagy löszerrel (Btk. 263/A §) büntettet. ${ }^{15}$

Az embercsempészés tényállásának újraszövegezése a schengeni végrehajtási egyezmény 27. cikkének első pontjára is figyelemmel történt, amely szerint: „, A Szerzödö Felek kötelezettséget vállalnak arra, hogy megfelelö büntetöintézkedéseket vezetnek be mindazokkal szemben, akik haszonszerzés céljából külföldieknek segitenek, vagy kísérletet tesznek az ilyen segítségre annak érdekében, hogy a Szerzödö Félnek, a külföldiek beléptetésére és tartózkodására vonatkozó törvényei megsértésével, ennek a területére külföldiek belépjenek, vagy ott tartózkodjanak."

Az újrakodifikált törvényi tényállás két lényeges különbséget mutat az előző szabályozáshoz képest. Egyrészt a tényállás akként bővült, hogy az embercsempészést a jogalkotó nem csupán a Magyar Köztársaság államhatárának, hanem bármely államhatárnak a jogellenes átlépéséhez kapcsolja. Másrészt szükült az alaptényállás annak következtében, hogy kikerült a célzat, vagyis a büncselekmény alapesetének megvalósulásához nem szükséges a vagyoni haszonszerzés céljából történő elkövetés. ${ }^{16}$

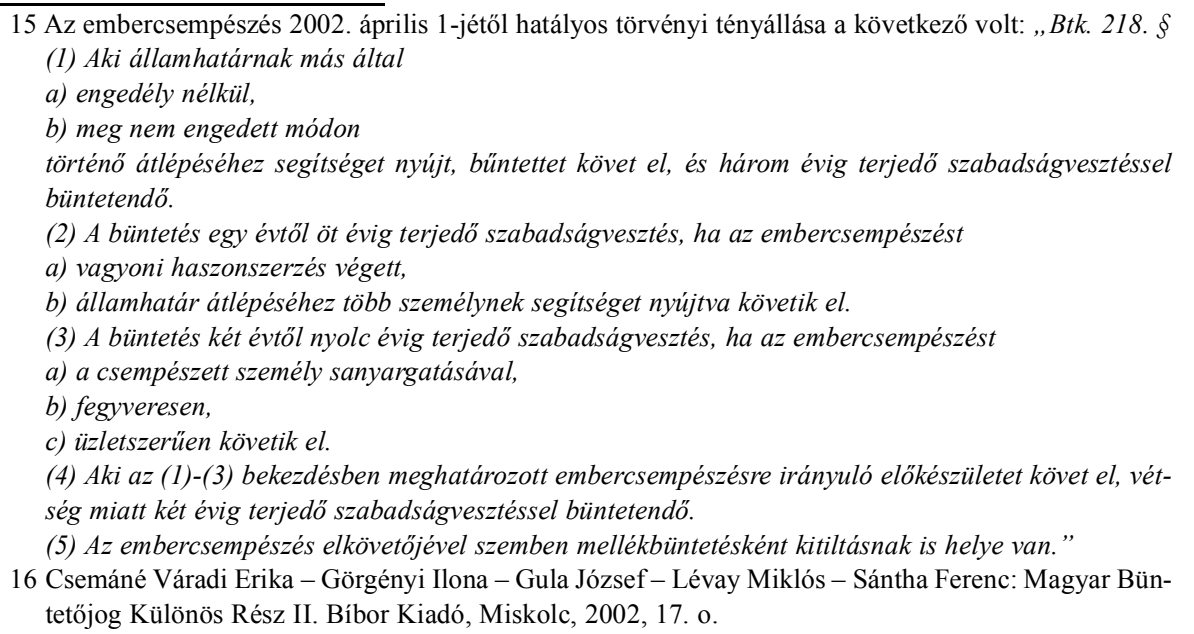


A célzat mellőzését elsősorban gyakorlati bünüldözési tapasztalatok indokolták, amelyek szerint az államhatár jogellenes átlépéséhez általában vagyoni haszonszerzés céljából nyújtanak segítséget ugyan, ennek a bizonyíthatósága azonban véletlenszerü körülményektöl függött. ${ }^{17}$

A jogalkotó a korábbi normaszöveggel ellentétben mellözte a bünszervezet tagjaként vagy megbízásából való elkövetést a minősített esetekből, mivel az ilyen módon történő elkövetések súlyosabb szankcionálását a módosult általános részi rendelkezések biztosítják. ${ }^{18}$

A 2012. évi C. törvénnyel kihirdetett új büntető törvénykönyv 2013. július 1-jén lépett hatályba, és a közigazgatás rendje elleni büncselekmények közé sorolta az embercsempészést. ${ }^{19}$

A büntetőjogi szabályozás a minősítő körülmények tekintetében a felfegyverkezve és a bünszövetségben elkövetett magatartásokkal bővült.

\section{Az embercsempészés hatályos büntetőjogi értelmezése}

A tömeges bevándorlás miatt megalkotott 2015. évi CXL. törvény három új tényállás büntetö törvénykönyvbe történő bevezetésével (határzár tiltott átlépése 352/A; határzár megrongálása 352/B; és határzárral kapcsolatos építési munka akadályozása 352/C §) biztosítja Magyarország államhatárának rendjét.

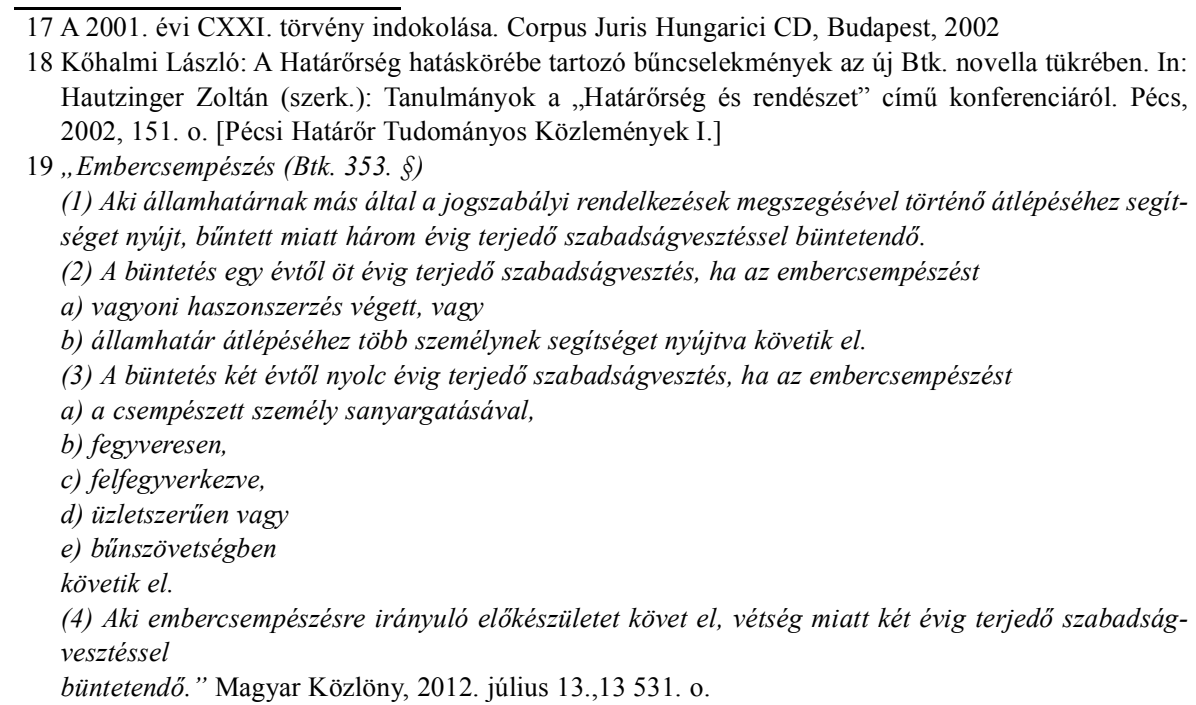


A 2015. szeptember 15-én hatályba lépő törvény továbbá az embercsempészésnek mind az alapesetét, mind a minősített eseteit jelentősen súlyosította.

„353. § (1) Aki államhatárnak más által a jogszabályi rendelkezések megszegésével történö átlépéséhez segitséget nyújt, büntett miatt egy évtöl öt évig terjedö szabadságvesztéssel büntetendö.

(2) A büntetés két évtöl nyolc évig terjedö szabadságvesztés, ha az embercsempészést

a) vagyoni haszonszerzés végett,

b) államhatár átlépéséhez több személynek segitséget nyújtva, vagy

c) az államhatár rendjének védelmét biztositó létesitmény, illetve eszköz megsemmisitésével vagy megrongálásával követik el.

(3) A büntetés öt évtöl tíz évig terjedő szabadságvesztés, ha az embercsempészést

a) a csempészett személy sanyargatásával,

b) fegyveresen,

c) felfegyverkezve,

d) üzletszerüen vagy

e) bünszövetségben követik el.

(4) A büntetés öt évtöl tizenöt évig terjedő szabadságvesztés, ha

a) a (3) bekezdés a) pontja szerinti embercsempészést a b)-e) pontban meghatározott módon

b) a (3) bekezdés b) pontja szerinti embercsempészést az a), illetve a c)-e) pontban meghatározott módon követik el.

(5) A (3) vagy (4) bekezdésben meghatározott büncselekmény szervezője vagy irányitója tíz évtöl húsz évig terjedö szabadságvesztéssel büntetendö.

(6) Aki embercsempészésre irányuló elökészületet követ el, három évig terjedö szabadságvesztéssel büntetendö."

A büncselekmény jogi tárgya az államhatár sérthetetlenségéhez, a határrendészeti előírások érvényesüléséhez füződő állami érdek, hogy mindenki csak jogszabályban vagy nemzetközi szerződésben meghatározott feltételek (engedély) teljesítése esetén lépje át az államhatárt.

$\mathrm{Az}$ államhatár átlépésének feltételeit részint nemzetközi szerződés, a schengeni végrehajtási egyezmény, részint a magyar törvények közül az államhatárról szóló 2007. évi LXXXIX. törvény és a harmadik országbeli állampolgárok beutazásáról és tartózkodásáról szóló 2007. évi II. törvény szabályozza. 
Az államhatár határozza meg az állami szuverenitás terét, az állam ezen belül gyakorolja korlátlan és oszthatatlan föhatalmát. ${ }^{20}$ Magyarország területét a föld felszínén függőlegesen áthaladó képzeletbeli síkok összessége (a továbbiakban: államhatár) határolja. Az államhatárnak a föld felszínén haladó vonalát nemzetközi szerződések határozzák meg, amelyeket törvényben kell kihirdetni. ${ }^{21}$ A határvonal az államhatár és a föld felszínének metszésvonala. ${ }^{22}$ Magyarország államhatárának vonalát a terepen elhelyezett határjelek jelölik.

Az elkövetési magatartás az államhatárnak más által a jogszabályi rendelkezések megszegésével történő átlépéséhez segítségnyújtás, azaz fogalmilag bünsegély [Btk. 14. § (2) bekezdés]. A jogalkotó a tiltott határátlépés szabálysértésnek minősülő cselekményhez kapcsolódó bünsegédi magatartást társadalomra fokozottan veszélyessége miatt önálló deliktumként szabályozza.

Segítségnyújtás minden olyan magatartás, amely bünsegély megállapítására alkalmas. A segítségnyújtás lehet fizikai vagy pszichikai. Fizikai segítségnyújtás például, ha az elkövető a tiltott határátlépést tervező személyt az államhatár közelébe szállítja, vagy az illetőt a gépjármüvében elrejtve jelentkezik átléptetésre a határátkelőhelyen. Pszichikai bünsegély például a tiltott határátlépésre készülő személy megfelelő információval, tanáccsal, útbaigazítással ellátása.

Az elkövetési magatartás kizárólag aktív tevékenység lehet. Az elkövetési magatartás az államhatár befelé, illetve kifelé történő átlépésével egyaránt megvalósítható. A törvényi tényállásból adódóan közömbös, hogy mely ország államhatárának átlépésére kerül sor.

Aki érvényes, az államhatár átlépésére jogosító úti okmánnyal nem bíró, harmadik országbeli állampolgárnak segítséget nyújt más schengeni tagállamba való beutazáshoz, attól függetlenül elköveti az embercsempészés büntettét, hogy ezen a „belső" határon van-e határellenőrzés. ${ }^{23}$

Az embercsempészés az elkövetési magatartás tanúsításával befejezetté válik, függetlenül attól, hogy az államhatár átlépésére sor került-e vagy a segítségnyújtás az államhatártól milyen távolságban történt. ${ }^{24}$

\footnotetext{
20 Belovics Ervin - Molnár Gábor - Sinku Pál: Büntetőjog Különös Rész. HVG-ORAC Lap- és Könyvkiadó Kft., Budapest, 2002, 247. o.

$21 \mathrm{Az}$ államhatárról szóló 2007. évi LXXXIX. törvény 1. § (1)-(2) bek.

22 Az államhatárról szóló 2007. évi LXXXIX. törvény 1. § (3) bek.

23 A Kúria 14/2013. számú büntető elvi határozata.

24 Erdősy Emil - Földvári József - Tóth Mihály: Magyar Büntetőjog Különös Rész. Osiris Kiadó, Budapest, 2002, 220. o.
} 
A büncselekmény kisérlete akkor állapítható meg, ha az elkövető az érintett személyekkel a törvényben meghatározott célból a kapcsolatot már felvette, a segítségnyújtás további mozzanatára azonban még nem került sor. ${ }^{25}$

A bủncselekmény alanya bárki lehet. Nincs akadálya társtettesség megállapításának sem, ha többen, egymás tevékenységéröl tudva és egymás tevékenységét kiegészítve nyújtanak segítséget másnak az államhatár jogellenes átlépéséhez.

Elvileg nincs akadálya a felbujtás megállapításának sem. Ilyen minősítésre akkor kerülhet sor, ha valaki a segítséget nyújtó személyt veszi rá az említett módon történő segítségnyújtásra. A felbujtónak természetesen tudnia kell a határátlépés módjáról is. ${ }^{26}$

A büncselekmény csak szándékosan követhető el. A tettes tudatában valamennyi objektív tényállási elemnek meg kell jelennie, tehát annak, hogy más vagy mások jogellenesen szándékoznak bármely ország államhatárát átlépni, s ehhez magatartásával segítséget nyújt.

Az új törvényi tényállásban négyféle súlyossági szinten összesen tizenegy minösitö körülmény található.

1. A (2) bekezdés a) pontja szerinti minősített eset a vagyoni haszonszerzési célzat, amelyre figyelemmel e minősített tényállás egyenes szándékkal követhető el. Az embercsempészés esetén a vagyoni haszonszerzésre irányuló célzat magában foglal minden olyan tevékenységet, amely a vagyoni gyarapodásra - akár az aktív vagyon követelésére, akár a passzív vagyon csökkentésére - irányul (BH, 2002/253.). A vagyoni haszonszerzési célzat akkor állapítható meg, ha az elkövető anyagi ellenszolgáltatás vagy előny, vagy tartozáselengedés fejében nyújt segítséget. Annak tényleges megszerzése azonban nem szükséges a befejezett büncselekmény megvalósulásához. A tényállás megállapítása szempontjából közömbös, hogy az anyagi előnyhöz ténylegesen hozzájutott-e az elkövetö, vagy sem.

2. A (2) bekezdés b) pontja törvényi egységet (delictum complexum) létesít arra az esetre, amikor az elkövető az államhatár átlépéséhez több személynek segítséget nyújtva valósítja meg az embercsempészést. E minősítő körülmény legalább két személy jogellenes határátlépéséhez nyújtott segítség esetén valósul meg. Ha az elkövető több személynek nyújt segítséget az államhatár átlépéséhez, nem többrendbeli büncselekményt kell megállapítani, hanem egyrendbeli, e pont szerinti minősített esetet. A 2001. évi CXXI. törvénnyel történő módosítás előtt annyi rendbeli embercsempészés bűn-

25 Belovics Ervin - Molnár Gábor - Sinku Pál: i. m. 248. o.

26 Erdősy Emil - Földvári József - Tóth Mihály: i. m. 220. o. 
cselekményének megállapítására került sor, ahány személy tiltott határátlépéséhez az elkövető segítséget nyújtott (BH, 1986/484.).

3. A (2) bekezdés c) pontja szerinti minősített eset az államhatár rendjének védelmét szolgáló létesítmény, illetve eszköz megsemmisítésével vagy megrongálásával történő elkövetés. Az államhatárról szóló 2007. évi LXXXIX. törvény 5. § (1) bekezdése alapján: ,,Magyarország területének a Közösségi Kódex 2. cikk 2. pontjának megfelelö külsö határ szerinti határvonaltól, illetve a határjeltöl számitott 60 méteres sávja az államhatár rendjének védelmét biztositó létesitmények-ideértve a 15/A. § szerinti létesitményeket is - épitése, telepitése és üzemeltetése, valamint a honvédelmi, nemzetbiztonsági, katasztrófavédelmi, határôrizeti, menekültügyi és idegenrendészeti feladatok ellátása céljából e törvény szerint igénybe vehető."

4. A súlyosabban büntetendő eseteket a (3) bekezdés tartalmazza. A (3) bekezdés a) pontjába ütközik annak az elkövetőnek a cselekménye, aki az embercsempészést a csempészett személy sanyargatásával követi el. Sanyargatással valósul meg a büncselekmény, ha az elkövetés a csempészett személynek testi vagy lelki szenvedést, gyötrelmet okoz. Ilyen az éheztetés, víz-, folyadékmegvonás, embertelen körülmények között, így sötét, fütetlen helyiségben tartás, életveszélyes megfenyegetés, vagy a hozzátartozókról olyan valótlan hírek közlése, amelyek rémület, illetve gyász elöidézésére alkalmasak.

5. A (3) bekezdés b) pontja alapján hasonlóan súlyos megítélés alá esik a fegyveresen történő elkövetés. A Btk. 459. § (1) bekezdés 5. pontja szerint fegyveresen követi el a büncselekményt, aki lőfegyvert, robbanóanyagot, robbantószert, robbanóanyag vagy robbantószer felhasználására szolgáló készüléket tart magánál. A fegyveres elkövetésre vonatkozó rendelkezéseket akkor is alkalmazni kell, ha a büncselekményt az előbbiek utánzatával fenyegetve követik el. A lőfegyver fogalmát a löfegyverekről és a lőszerekről szóló 2004. évi XXIV. törvény 2. § 16. pontja határozza meg, ennek értelmében lőfegyver: a tüzfegyver, valamint az a légfegyver, amelyből 7,5 joule-nál nagyobb csőtorkolati energiájú, szilárd anyagú lövedék lőhető ki. Robbanóanyag az olyan, kifejezetten erre a célra előállított anyag, keverék, vagy vegyület, amely valamilyen mechanikai, hö, elektromos, vegyi behatás, illetve ilyen jel következtében igen rövid idő alatt nagy hö, fény, hang, nyomás, feszítőerő kifejtése mellett alakul át, és ily módon romboló hatást vált ki. A robbantószer pedig olyan anyag, illetve anyagkeverék, amely igen nagy mennyiségü kémiai energiát tárol, és égés során nagyon rövid idő alatt nagy energia leadására, azaz robbanásra képes. 
6. A (3) bekezdés c) pontja szerint szintén súlyosan büntetendő a felfegyverkezve megvalósuló elkövetés. A Btk. 459. § (1) bekezdés 6. pontja alapján felfegyverkezve követi el a büncselekményt, aki az ellenállás leküzdése vagy megakadályozása érdekében az élet kioltására alkalmas eszközt tart magánál.

7. A (3) bekezdés d) pontja az előző esetekkel azonosan értékeli az üzletszerüen történő elkövetést. Az üzletszerüség fogalmára a Btk. 459. § (1) bekezdés 28. pontja az irányadó, amely szerint üzletszerüen követi el a büncselekményt, aki ugyanolyan vagy hasonló jellegü büncselekmények elkövetése révén rendszeres haszonszerzésre törekszik. A bírói gyakorlat értelmében az embercsempészés üzletszerüen elkövetett, ha az elkövető e célra alakult szervezet tagjaként, bár első ízben valósítja meg a büncselekményt (BH, 1981/267.).

8. A (3) bekezdés e) pontja büntetni rendeli a bünszövetségben megvalósuló elkövetést. A Btk. 459. § (1) bekezdés 2. pontja szerint bünszövetség akkor létesül, ha két vagy több személy büncselekményeket szervezetten követ el, vagy ebben megállapodik, és legalább egy büncselekmény elkövetését megkísérlik, de nem jön létre búnszervezet.

9. A (4) bekezdés a) pontja alapján még súlyosabb megítélés alá esik, ha a csempészett személy sanyargatásával megvalósuló embercsempészést fegyveresen, felfegyverkezve, üzletszerüen vagy bünszövetségben követik el.

10. A (4) bekezdés b) pontja az előző esetekkel azonosan értékeli a fegyveresen történő embercsempészést, amennyiben az a csempészett személy sanyargatásával, felfegyverkezve, üzletszerüen vagy bűnszövetségben valósul meg.

11. Az (5) bekezdés alapján legsúlyosabban az embercsempészés büncselekmény szervezője vagy irányítója büntetendő.

Az embercsempészésnek az elökészülete is büntetendö, így aki a büncselekmény elkövetése céljából az ehhez szükséges vagy ezt könnyítő feltételeket megteremti, az elkövetésre felhív, ajánlkozik, vállalkozik, vagy a közös elkövetésben megállapodik. Mind az alapeseti, mind a minősített esetekben meghatározott embercsempészésre irányuló előkészület büntetéssel fenyegetett. A bírói gyakorlat szerint az embercsempészés előkészületét valósítja meg, aki vállalkozik másoknak az államhatáron való átkísérésére, de a határt illegálisan átlépni szándékozó személyeket a határőrök elfogják (BH, 2000/333.).

Mellékbüntetésként kitiltásnak is helye van a Btk. 364. § rendelkezése szerint. A Btk. 57. §-a alapján törvényben meghatározott esetekben azt, akinek otttartózkodása a közérdeket veszélyezteti, egy vagy több településről, vagy egy 
település, illetve az ország meghatározott részéből ki lehet tiltani. A kitiltás legrövidebb tartama egy, leghosszabb tartama öt év. A kitiltás mint mellékbüntetés az elkövető azon jogát korlátozza, hogy tartózkodási helyét szabadon választhassa meg. A kitiltás alkalmazásának két lényeges korlátja van. Az egyik, hogy e mellékbüntetés csak a törvényben meghatározott büncselekmények esetén alkalmazható. A másik lényeges korlát az, hogy a szabadságvesztésen kívül más büntetési nem mellett ugyancsak nem kerülhet sor e mellékbüntetésre. A szabadságvesztésnek nem kell szükségszerüen végrehajtandónak lennie, a kitiltás alkalmazható próbaidőre felfüggesztett szabadságvesztés kiszabása mellett is.

Az egység-halmazati kérdések tekintetében az embercsempészés halmazatba kerülhet egyéb büncselekményekkel is, leggyakrabban a közokirat-hamisítás büntettével.

Bünhalmazat létesül akkor, ha a segítségnyújtás az embercsempészés mellett más büncselekményt is megvalósít, így például külföldre távozás elösegítése céljából, ellenszolgáltatásért útlevél meghamisítása, hivatalos személy által kötelességszegéssel elkövetett vesztegetés büntette és hivatalos személy által közokirat-hamisítás büntette mellett embercsempészet büntettének is minősül az, ha a meghamisított útlevél felhasználásával az országot elhagyták (BH, 1988/120.).

Ha az embercsempészés során a csempészett személy meghal, vagy testi sérülést szenved, a bünösségtől függően szándékos vagy gondatlan emberölés, illetve testi sértés halmazata az embercsempészés alapesetével állapítható meg.

Az embercsempészést a jogellenes tartózkodás elősegítésétől az határolja el, hogy míg utóbbi elkövetője jogtalan vagyoni haszonszerzés céljából, kizárólag a jogellenes belföldi tartózkodáshoz nyújt segítséget, de az országba belépést semmilyen módon nem segíti, addig az embercsempészés, amely alapesetben a vagyoni haszonszerzés célzatát nem tartalmazza, nemcsak a belföldön tartózkodást, hanem az országba belépő, akár onnan kilépő oldalon az államhatár tiltott, vagy meg nem engedett módon való átlépését segíti. Az elkövető cselekménye olyan személy jogellenes határátlépését is segítheti, akinek a belföldön tartózkodása egyébként nem jogellenes (BH, 2011/157.).

\section{Összegzés}

A magyar jogrendszerben az embercsempészés büntetőjogi szabályozása permanens jogalkotási folyamat része, amelynek gyökerei a XIX. század végére nyúlnak vissza, és napjainkban sem zárható le. 
A jogalkotó a társadalom védelmének elve alapján az embercsempész tevékenységet mint a társadalomra veszélyes emberi magatartást büncselekménnyé nyilvánította és büntetni rendelte. A tényállás természetét és alakulását az adott korszak társadalmi viszonyai, valamint az állam büntetőjogi akarata határozta meg.

Összegezve megállapítható, hogy a következő években továbbra is számolni kell ezzel a jelenséggel. Az embercsempészés elleni fellépés nemcsak szigorú jogi hátteret, hanem összehangoltabb és hatékonyabb nemzetközi együttmüködést is kíván. Az okok és megoldások valójában messze túlnőnek a nemzeti kompetenciákon, közös európai uniós erőfeszítéseket igényelnek. ${ }^{27}$

\section{IRODALOM}

Belovics Ervin - Molnár Gábor - Sinku Pál: Büntetőjog Különös Rész. HVG-ORAC Lapés Könyvkiadó Kft., Budapest, 2002

Csemáné Váradi Erika - Görgényi Ilona - Gula József - Lévay Miklós - Sántha Ferenc: Magyar Büntetőjog Különös Rész II. Bíbor Kiadó, Miskolc, 2002

Erdősy Emil - Földvári József - Tóth Mihály: Magyar Büntetőjog Különös Rész. Osiris Kiadó, Budapest, 2002

Földvári József: Büntetőjog Különös Rész. Janus Pannonius Tudományegyetem Állam- és Jogtudományi Kar-Tankönyvkiadó, Budapest, 1972

Gaál Gyula: Az embercsempész tevékenység megjelenési formáinak és módszereinek változásai a Magyar Köztársaság államhatárán 1991-2003 között. Doktori (PhD) értekezés. Zrínyi Miklós Nemzetvédelmi Egyetem, Budapest, 2005

Hautzinger Zoltán: Idegen a büntetőjogban. AndAnn Kiadó, Pécs, 2016

Kőhalmi László: A Határőrség hatáskörébe tartozó bủncselekmények az új Btk. novella tükrében. In: Hautzinger Zoltán (szerk.): Tanulmányok a „Határőrség és rendészet” című konferenciáról. Pécs, 2002. 151. o. [Pécsi Határőr Tudományos Közlemények I.]

Németh József: A Rendőrség feladatai az illegális migráció és a nemzetközi terrorizmus elleni fellépés terén különös tekintettel a Balkán biztonsági helyzetére. Doktori $(\mathrm{PhD})$ értekezés. Zrínyi Miklós Nemzetvédelmi Egyetem, Budapest, 2011

Verhóczki János: Az embercsempészés a mai magyar büntetőjogban. Magyar Rendészet, 2000/5-6.

27 Lásd Hautzinger Zoltán: Idegen a büntetőjogban. AndAnn Kiadó, Pécs, 2016. 